Bull. Geol. Soc. Finland 41, 47-50 (1969)

\title{
RANKAMAITE, A NEW TANTALUM MINERAL FROM KIVU, CONGO
}

\author{
Oleg von Knorring*, Atso Vorma** and Peter H. Nixon *** \\ * University of Leeds, England \\ ** Geological Survey of Finland, Otaniemi, Finland \\ *** Geological Survey and Mines Department, Entebbe, Uganda
}

\begin{abstract}
Rankamaite is a new alkali tantalate found in heavy mineral concentrates from alluvial deposits, Mumba area, Kivu, eastern Congo, as water-worn pebbles up to tens of grams in weight. The mineral constitutes the matrix in which corroded grains of simpsonite, minute crystals of cassiterite and some manganotantalite and muscovite are seen. It was probably formed by alteration of simpsonite; the source rock is probably a lithium pegmatite. The chemical analysis gave: $\mathrm{Ta}_{2} \mathrm{O}_{5} 69.47, \mathrm{Nb}_{2} \mathrm{O}_{5} 17.40, \mathrm{Al}_{2} \mathrm{O}_{3} 3.40, \mathrm{Li}_{2} \mathrm{O} 0.11, \mathrm{Na}_{2} \mathrm{O} 2.31, \mathrm{~K}_{2} \mathrm{O} 1.80, \mathrm{PbO} 2.63, \mathrm{H}_{2} \mathrm{O}+1.55, \mathrm{H}_{2} \mathrm{O}-0.35$, $\mathrm{SiO}_{2} 0.96$, sum $99.98 \%$. After correcting for muscovite, this gives for the unit cell content $\left(\mathrm{Na}_{3.45} \mathrm{~K}_{1.52} \mathrm{~Pb}_{0.55} \mathrm{Li}_{\mathbf{0} .34}\right)$ $\left(\mathrm{Ta}_{13 \cdot 75} \mathrm{Nb}_{6.06} \mathrm{Al}_{2 \cdot 35}\right) \mathrm{O}_{56.52}(\mathrm{OH})_{7 \cdot 48}$ or $(\mathrm{Na}, \mathrm{K}, \mathrm{Pb}, \mathrm{Li})_{5 \cdot 86}(\mathrm{Ta}, \mathrm{Nb}, \mathrm{Al})_{22 \cdot 16}(\mathrm{O}, \mathrm{OH})_{60}$.

The X-ray study shows that the powder pattern can be indexed on the basis of an orthorhombic unit cell, with $a_{o}=17.19, b_{o}=17.70, c_{o}=3.933 \AA$. If only reflections, with $b+k=$ even, are considered, the possible space groups are $C 222, C m m 2, C m 2 m$, and $C m m m$. The powder data are comparable to those of tetragonal $\mathrm{SrTa}_{4} \mathrm{O}_{11}$ and $\mathrm{K}_{2} \mathrm{Nb}_{8} \mathrm{O}_{21}$ and also to those of orthorhombic $\mathrm{PbNb}_{2} \mathrm{O}_{6}$; all these synthetic compounds are structurally related to the tungsten bronzes. The strongest X-ray lines are 4.112 (34), 3.935 (41), $3.467(52), 3.375$ (60), $3.011(80), 2.970(100), 1.736$ (32).

The colour is white to creamy-white. $H$ is difficult to determine, but is approximately $3-4 . G$ is about 5.5 (meas.), 5.84 (calc.). In thin section it is felt-like, somewhat resembling fibrous sillimanite. Elongation is positive, $Z \| c, X \perp c$, $n$ s above 2.1. The name is in honour of Professor Kalervo Rankama of the University of Helsinki, who has made a major contribution to the geochemistry of tantalum and niobium.

The name rankamaite was approved in advance of publication by the Commission on New Minerals and Mineral Names of the I.M.A.
\end{abstract}

\section{Introduction}

Nodules composed of vitreous colourless to creamy simpsonite embedded in the new soft, white fibrous mineral, rankamaite, together with scattered grains and aggregates of a dark-grey to black cassiterite have been submitted for identification to the laboratories of the Geological
Survey and Mines Department, Uganda, on several occasions since 1961 . These specimens have always been accompanied by rounded nodules of manganotantalite; both are manifestly of alluvial origin. Some of the first specimens examined were sent by Monsieur R. Deschodt of Gisenyi, Rwanda, who stated that they were from the Kivu province, Congo. 
Preliminary data on this new mineral were given by one of us (O.v.K.) in the Annual Reports of the Research Institute of African Geology at Leeds (von Knorring, 1962 and 1965). In 1965, Monsieur A. Safiannikoff of the Compagnie Minière Congolaise des Grands Lacs, Kamituga, Kivu, Congo, stated in a written communication that the above assemblage was typically found in alluvial deposits, probably derived from spodumene-bearing pegmatites between Goma and Masisi to the north-west of Lake Kivu. These deposits are worked for cassiterite and manganotantalite which occur together with simpsonite and microlite, including a lead-rich caesium-bearing variety of the latter (Safiannikoff and van Wambeke, 1961). Safiannikoff concludes that the fibrous mineral which is associated with the viterous simpsonite is similar to simpsonite in composition but contains a higher proportion of niobium. No doubt M. Safiannikoff was aware of the existence of the fibrous mineral (rankamaite) long before it was observed by us.

According to M. Antonio Bertossa, director of the Geological Survey of Rwanda, the present mineral has been recovered from the alluvial cassiterite concentrates in the Mumba area in Kivu.

In this general area Agassiz (1954) has recognized three distinct types of mineralized pegmatites associated with Burundian granitic intrusives. Their order from the granite contact outwards is as follows:

1) Pegmatites with black tourmaline, potash feldspar and muscovite; some of these pegmatites carry beryl crystals of a characteristic »beige blanchâtre» colour; maximum width of pegmatites some $20 \mathrm{~m}$.

2) Kaolinized as well as zoned pegmatites with muscovite, quartz, microcline, albite, spodumene and some amblygonite. These kaolinized pegmatites often contain lepidolite and the common mineralization is cassiterite as well as a variety of tantalum-niobium minerals e.g., columbite-tantalite, tapiolite, manganotantalite, simpsonite and microlite. The pegmatites are larger than those of the previous group, sometimes up to $40 \mathrm{~m}$ in width.

3) The third group consists of cassiteritebearing quartz veins no more than 1 metre across.

\section{Physical properties and paragenesis of ran- kamaite}

Specimens of rankamaite have been found as nodules up to $100 \mathrm{~g}$ in weight. The mineral constitutes the silky, fibrous (asbestiform) matrix in which corroded grains of simpsonite and crystals of cassiterite are seen (Fig. 1). The colour of rankamaite is white to creamy-white or yellowish due to iron staining. The fibres are generally wavy but tufts of straight fibres can be seen in small cavities. The hardness is approximately 3-4; specific gravity about 5.5 (meas.) and 5.84

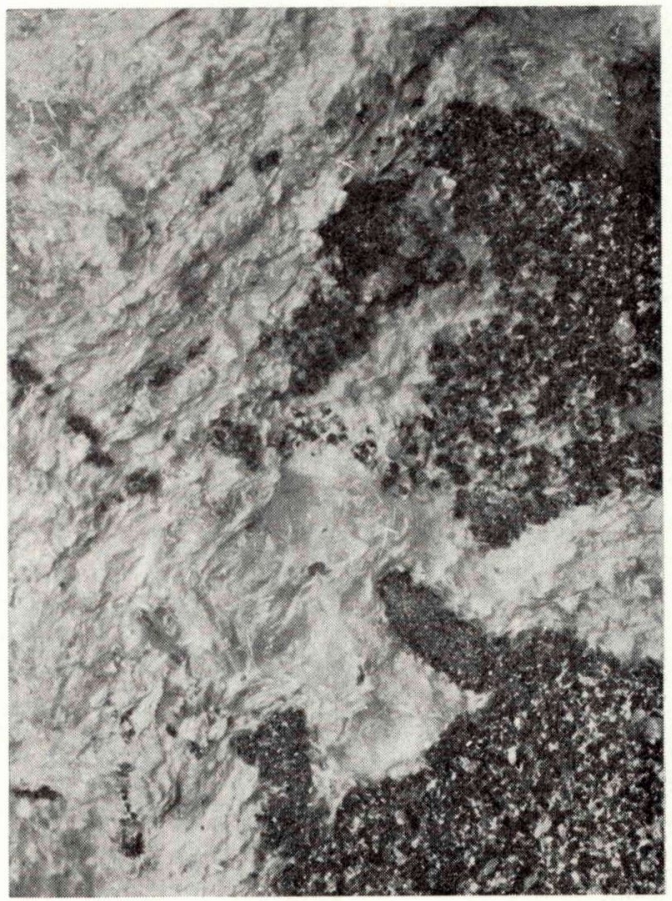

Fig. 1. Rankamaite with simpsonite and black cassiterite. $10 \times$. 
(calc.). In thin sections, the mineral is felt-like in appearance and bluish-grey in colour; some bundles of fibres appear brownish and resemble fibrous sillimanite. The elongation of rankamaite is positive, $Z \| c$ and, $X \perp c$; the refractive indices are greater than 2.10 .

The content of simpsonite in the specimens varies from some 10 to 80 per cent. It occurs in rounded or kidney-shaped grains up to $10 \mathrm{~mm}$ across, but even larger irregular masses are often observed. Sometimes distinctly concentric layers of rankamaite are seen around simpsonite. Small vugs filled with granular, secondary microlite have occasionally been noticed in simpsonite.

Cassiterite occurs either in the form of veinlets, irregular grains with crystal outlines or closely packed aggregates of minute, black, diamond-shaped crystals (Fig. 2). The content of cassiterite varies from about $5-10$ per cent. In most cases it is embedded in rankamaite, but it may also be associated with simpsonite, fibrous

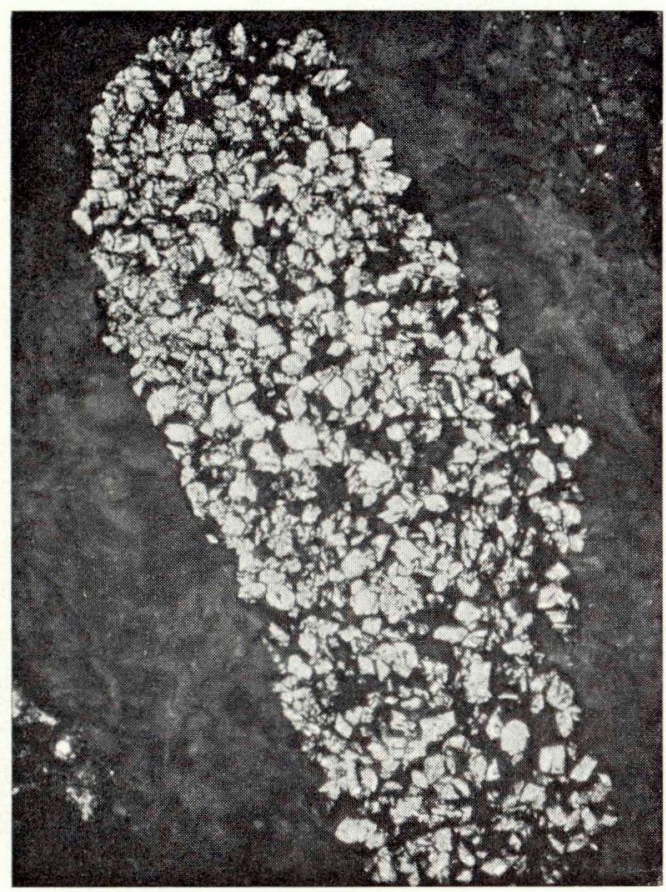

Fig. 2. Aggregate of cassiterite crystals in rankamaite. $40 \times$. manganotantalite and, occasionally, with kaolinite. The minute cavities in cassiterite may contain some clear, colourless beryl.

Manganotantalite is dark-red or brownish-red in colour and is present in small amounts in some rankamaite specimens, usually in the form of minute grains or in radiating sheaves or aggregates. The mica seems to be of two kinds: finely divided muscovite occurs in small amounts amongst the rankamaite (probably a by-product of simpsonite replacement) and small books of muscovite are scattered throughout the specimens.

An apparent order of mineral formation could be: simpsonite, rankamaite, manganotantalite, cassiterite.

Previous workers (e.g., Bowley, 1939, Macgregor, 1946) have observed that simpsonite is frequently altered to a varying degree. In addition to an isotropic alteration product (microlite), an anisotropic mineral is commonly seen.

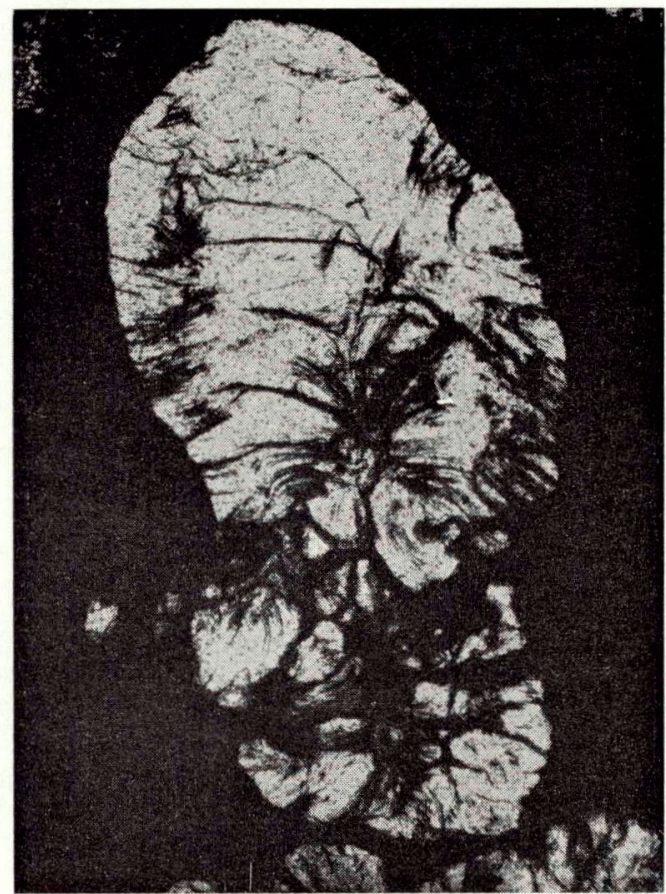

Fig. 3. Corroded simpsonite partly replaced by fibrous rankamaite. $30 \times$. 
On the alteration of simpsonite from Bikita, Macgregor writes: "The principal product is an unidentifiable mineral in the form of minute colourless, apparently rhombic prisms with approximately straight extinction and positive elongation.» Could this mineral observed by Macgregor also have been rankamaite? In the present case, simpsonite is seen in various stages of alteration to rankamaite (Figs. 3 -4). If the original simpsonite is fractured, replacement proceeds mainly along the cracks; moreover, there is a characteristic radial replacement by finely fibrous rankamaite affecting the margins (Fig. 3). If, on the other hand, the simpsonite grains are solid, a marginal replacement with the formation of concentric rankamaite is more in evidence. All these replacement processes are considered to have taken place during a late phase of intensive alkali metasomatism (mainly $\mathrm{Na}$ ) so commonly observed in complex pegmatites within the Kibaran belt.

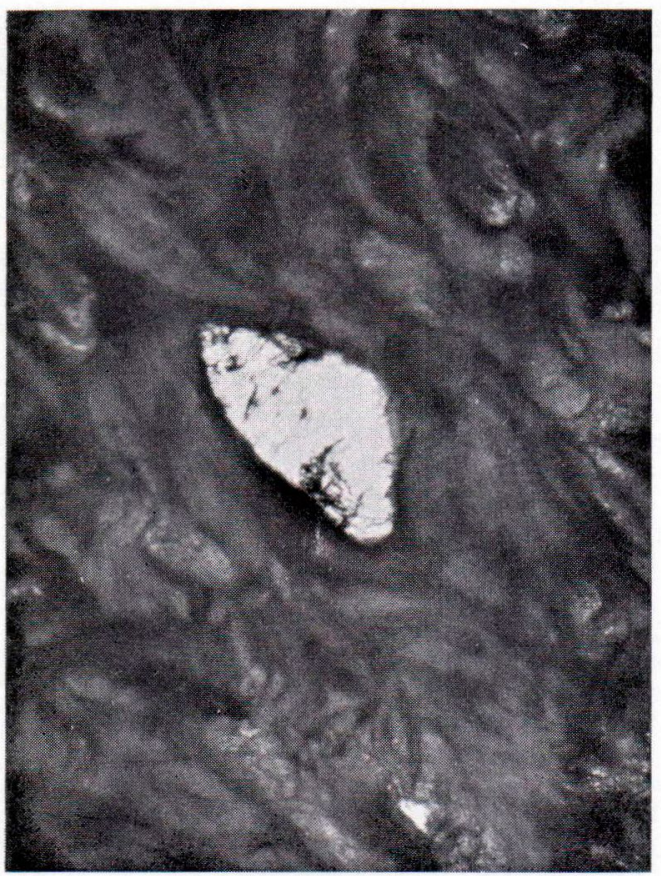

Fig. 4. Remnant of simpsonite in rankamaite matrix. $75 \times$.

\section{X-ray crystallography}

The mineral was investigated by X-ray powder and single-crystal methods. Since the crystals were very thin, only fibre photographs could be taken with the oscillation camera. The reflections on the film (camera dia. $3 \mathrm{~cm}$ ) appeared as arcs about $10 \mathrm{~mm}$ long. The identity period parallel to the fibre direction could, however, be determined: $3.9 \AA$ parallel to the orthorhombic $c$-axis of rankamaite. Even small crystals, with diameters less than $0.01 \mathrm{~mm}$, when investigated with a Norelco microcamera gave good layer lines, indicating that the »crystals» were actually crystal bundles.

The X-ray powder pattern (Table 1) was recorded with a Philips wide-range diffractometer with a rotating specimen holder and filtered copper radiation. Silicon was used as the internal standard. The low- $\Theta$-reflections were calibrated with $\mathrm{Pb}\left(\mathrm{NO}_{3}\right)_{2}$ using another preparate. The powder pattern can be indexed on the basis of an orthorhombic unit cell with

$$
\begin{aligned}
& a_{0}=17.19 \AA \\
& b_{0}=17.70 \AA \\
& c_{0}=3.933 \AA
\end{aligned}
$$

Table 1 shows that almost all the $\sin ^{2} \Theta$ values corresponding to one $\mathrm{bkl}$ index are such that $b+k=$ even. The only exception is the weak reflection 121 at $3.529 \AA$. Presumably, rankamaite has a $C$-centered lattice or one which is very nearly so. If only reflections with $b+k=$ even exist, the possible space groups are: $C 222$, $C m m 2, C m 2 m$, and $C m m m$.

In Table 1 the rankamaite powder data are compared with those of the tetragonal $\mathrm{Sr}^{\prime} \mathrm{Ta}_{4} \mathrm{O}_{11}$ (Gasperin, 1963), a compound of tungsten bronze-type structure, and with those of $\mathrm{K}_{2} \mathrm{Nb}_{8} \mathrm{O}_{21}$ (Guerchais, 1962). It is evident that these last two compounds are similar in structure and that the rankamaite powder pattern bears some similarity to them.

The tetragonal axes of $\mathrm{SrTa}_{4} \mathrm{O}_{11}$ are: $a_{0}=3$ $\times 17.53 \AA$ and $c_{0}=2 \times 3.865 \AA$. The ranka- 
TABLE 1

Comparison of the $\mathrm{X}$ - ray powder data of rankamaite with those of the synthetic $\mathrm{SrTa}_{4} \mathrm{O}_{11}$ and $\mathrm{K}_{2} \mathrm{Nb}_{8} \mathrm{O}_{21}$

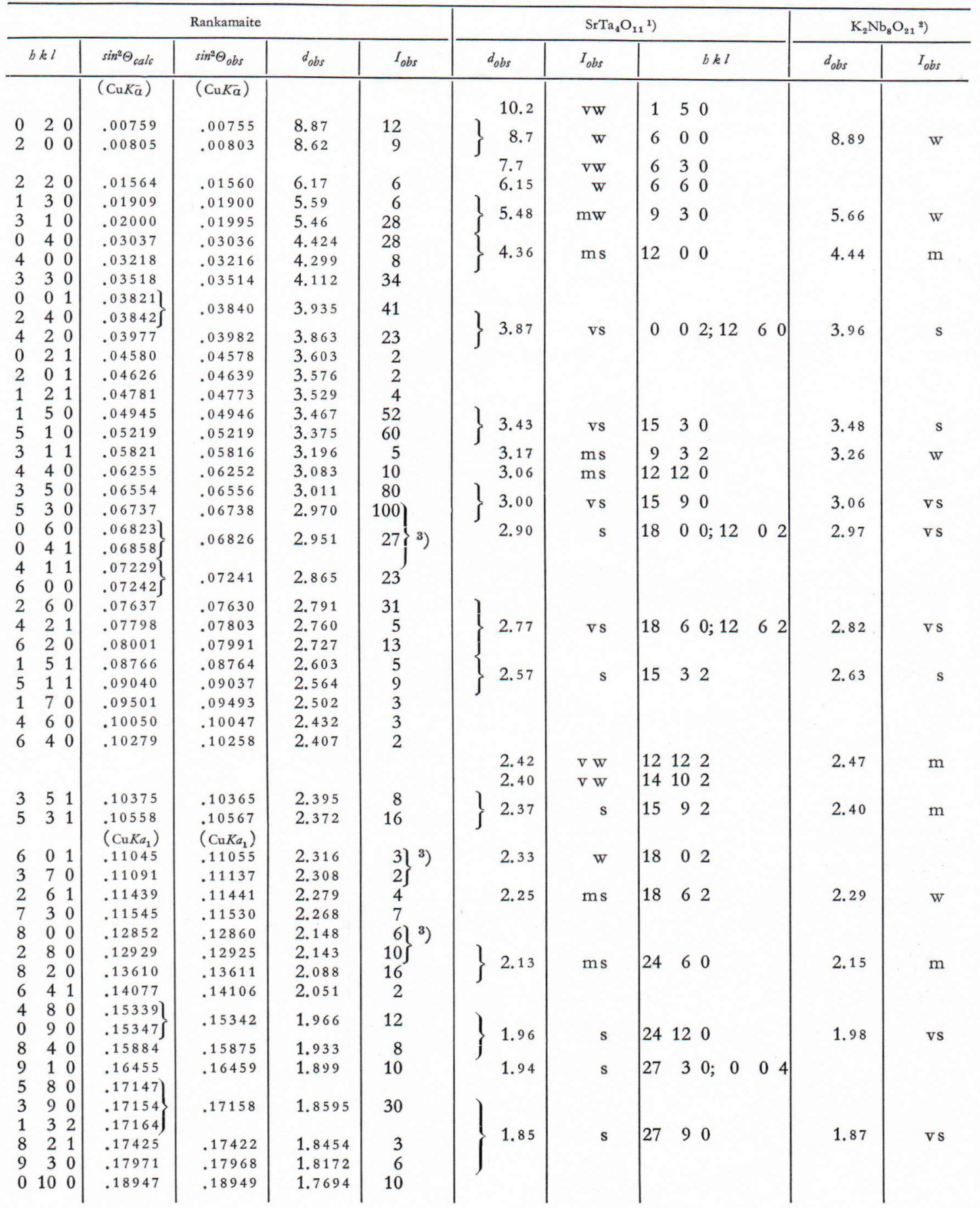




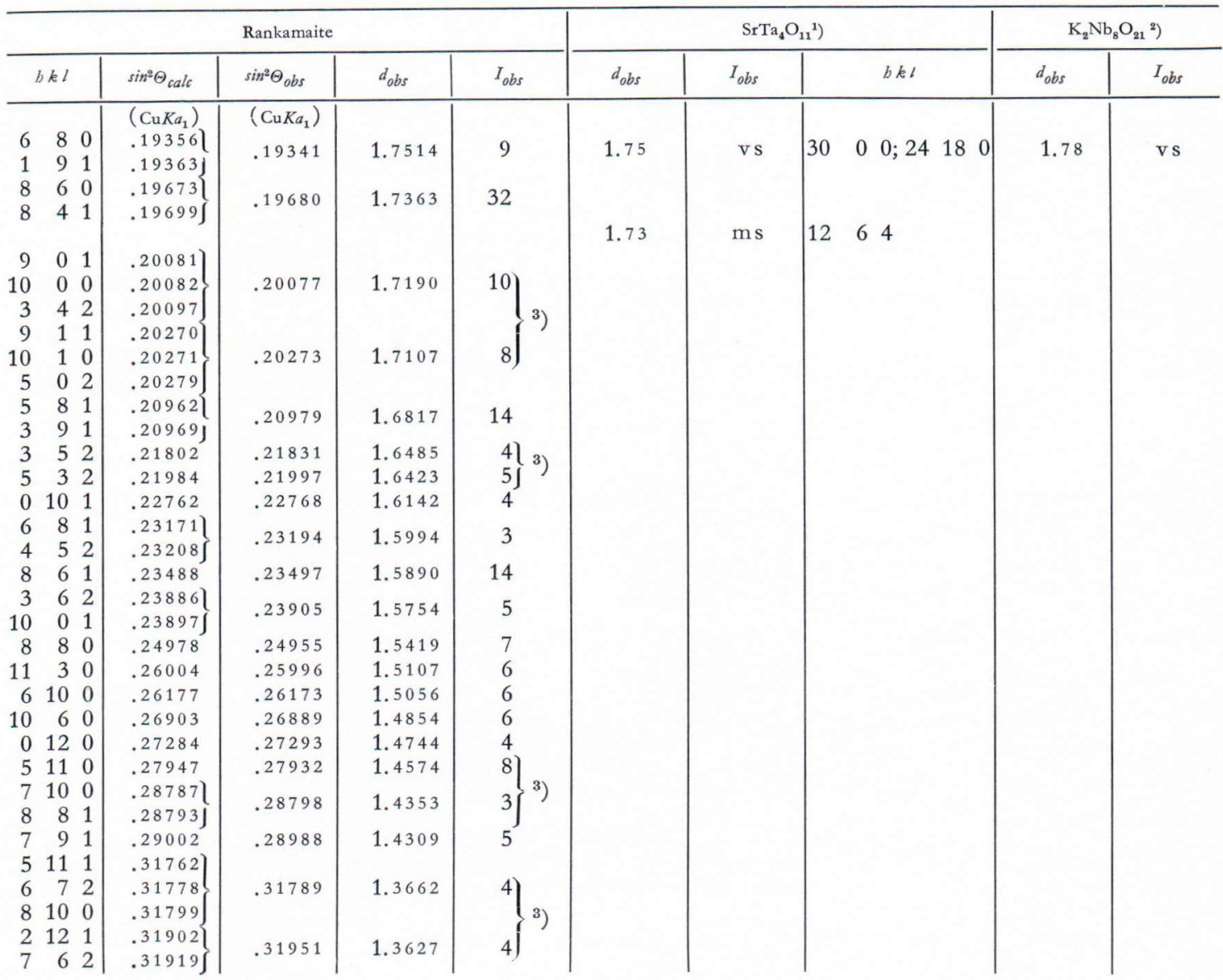

1) Gasperin, 1963.

2) Guerchais, 1962.

3) Partial overlapping of reflections.

maite unit cell is a sub-cell of this. The tungsten bronze-type sub-cell of $\mathrm{SrTa}_{4} \mathrm{O}_{11}$ has the tetragonal $a_{0}{ }^{\prime}=12.40 \AA(=17.53 / \sqrt{2})$ and $c_{0}{ }^{\prime}=$ $3.865 \AA$. When the orthorhombic rankamaite axes are transformed according to $\frac{1}{2} \frac{1}{2} 0 / 001 / \frac{1}{2} \frac{1}{2} 0$ one obtains the same cell-slightly deformed:

$$
\begin{aligned}
& a_{o}{ }^{\prime}=12.34 \AA \\
& b_{o}{ }^{\prime}=3.933 \AA \\
& c_{0}{ }^{\prime}=12.34 \AA \\
& \beta=91^{\circ} 41^{\prime}
\end{aligned}
$$

These data and Table 1 show that rankamaite has a slightly deformed tungsten bronze type structure. The splitting of the reflections through this deformation is easily seen when comparing the powder data of the orthorhombic rankamaite with those of the tetragonal $\mathrm{Sr}^{\top} \mathrm{Ta}_{4} \mathrm{O}_{11}$ and $\mathrm{K}_{2} \mathrm{Nb}_{8} \mathrm{O}_{21}$.

When the powder data of rankamaite are compared with those of the high temperature form of $\mathrm{PbNb}_{2} \mathrm{O}_{6}$ (see Roth, 1957), also structurally related to tungsten bronzes, it becomes clear that these powder patterns have much in common. $\mathrm{PbNb}_{2} \mathrm{O}_{6}$ has an orthorhombic space 
group $C 222$ or $C m m 2$ ( $c f$., rankamaite). Its axes are: $a_{o}=17.63, b_{o}=17.93$ and $c_{o}=3.868 \AA$ (cf., Table 3). These are similar to those of rankamaite. Owing to its fibrous nature the $\mathrm{X}$ ray preparate consists of very well oriented rankamaite, the $c$-axis being parallel to the surface of the specimen holder. This enhances all the $b k 0$ reflections while all the $b k l$ reflections decrease in intensity. Roth (op. cit.) does not mention the morphology of the $\mathrm{PbNb}_{2} \mathrm{O}_{6}$ crystals nor the method used to obtain the powder data. A rough comparison of rankamaite and $\mathrm{PbNb}_{2} \mathrm{O}_{6}$ shows very close similarity in the intensities of the bk0-type reflections, while the $b k l$-type reflections of the $\mathrm{PbNb}_{2} \mathrm{O}_{6}$ are stronger than those of rankamaite. This is certainly due to the oriented preparate of rankamaite.

The above comparisons leave no doubt that rankamaite has in fact a distorted tungsten bronze-type structure.

\section{Chemical composition}

The chemical composition of rankamaite is given in Table 2. The small amount of $\mathrm{SiO}_{2}$ is attributed to muscovite, the remainder repre- sents rankamaite. X-ray crystallography shows the mineral to be structurally related to tungsten bronzes, in which the sub-cell contains 30 oxygen atoms. The atomic proportions in Table 2 are recalculated on the basis of $(\mathrm{O}+\mathrm{OH})=60$, i.e., two tungsten bronze $=$ one rankamaite cell. The unit cell content is $\left(\mathrm{Na}_{3.45} \mathrm{~K}_{1.52} \mathrm{~Pb}_{0.55} \mathrm{Li}_{0.34}\right)$ $\left(\mathrm{Ta}_{13.75} \mathrm{Nb}_{6.06} \mathrm{Al}_{2.35}\right)\left(\mathrm{O}_{52.62}(\mathrm{OH})_{7.48}\right)$ or simplified, ( $\mathrm{Na}, \mathrm{K}, \mathrm{Pb}, \mathrm{Li})_{5.86}(\mathrm{Ta}, \mathrm{Nb}, \mathrm{Al})_{22.16}$ $(\mathrm{O}, \mathrm{OH})_{6 \mathbf{0}}$. Based on 6 oxygen atoms $(Z=10)$ the rankamaite formula can be written $(\mathrm{Na}, \mathrm{K}, \mathrm{Pb}, \mathrm{Li})_{0.586}(\mathrm{Ta}, \mathrm{Nb}, \mathrm{Al})_{2.216}(\mathrm{O}, \mathrm{OH})_{6}(c f$., Table 3). The ratio of small cations ( $\mathrm{Ta}, \mathrm{Nb}, \mathrm{Al})$ to anions $(\mathrm{O}, \mathrm{OH})$ is not ideal for the tetragonal tungsten bronze-type structure $(1: 3)$. This will be discussed in the next section.

The chemical analysis shows that rankamaite is an alkali tantalate in which some of the alkalies are replaced by lead and some of the tantalum by niobium and aluminium (?). In composition rankamaite corresponds to the synthetic compound $\mathrm{Na}_{2} \mathrm{Ta}_{8} \mathrm{O}_{21}$ which, recalculated on the basis of six oxygen atoms, gives $\mathrm{Na}_{0.572}{ }^{\mathrm{T}} \mathrm{Ta}_{2.286} \mathrm{O}_{6}$. The structure of this synthetic compound is similar to that of rankamaite but presumably not identical (see Table 3 ).

TABLE 2

Chemical composition and unit cell content of rankamaite. Mumba, Kivu Province, Congo. Anal. Oleg v. Knorring

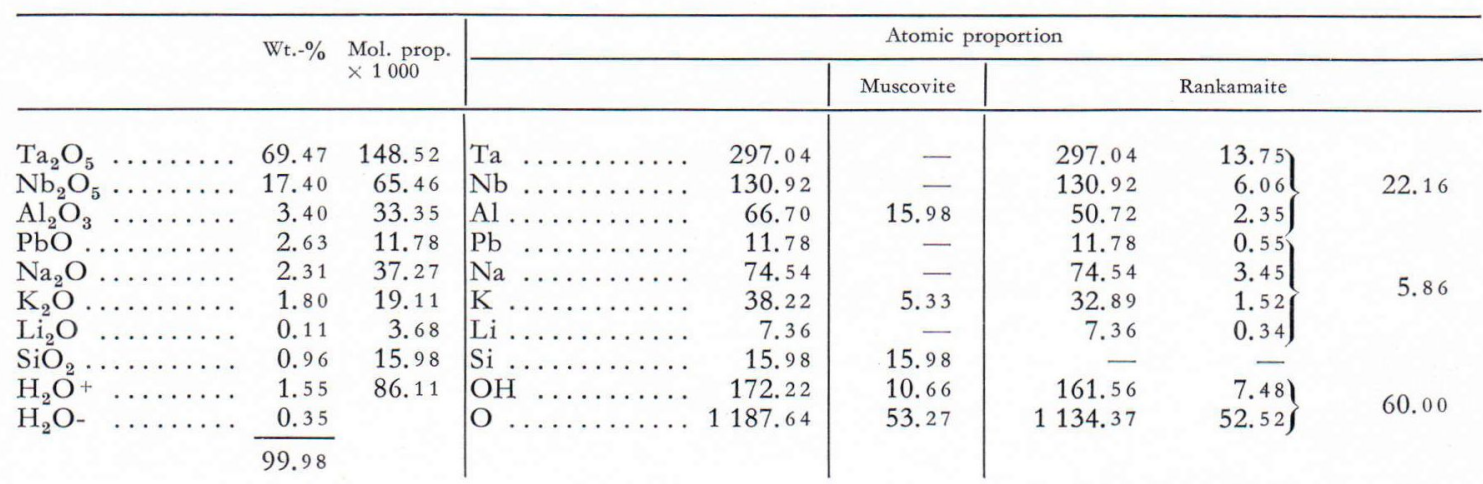

Unit cell content: $\left(\mathrm{Na}_{3.45} \mathrm{~K}_{1.52} \mathrm{~Pb}_{0.55} \mathrm{Li}_{0.34}\right)\left(\mathrm{Ta}_{13.75} \mathrm{Nb}_{6.06} \mathrm{Al}_{2.35}\right)\left(\mathrm{O}_{52.52}(\mathrm{OH})_{7.48}\right)$. 
TABle 3

Comparison of rankamaite unit cell with compounds structurally related to tungsten bronzes

\begin{tabular}{|c|c|c|c|c|c|c|c|c|}
\hline \multirow[t]{2}{*}{$\frac{\text { Unit cell content }}{Z}$} & \multirow[t]{2}{*}{$\begin{array}{c}\frac{\xi}{5} \\
\frac{5}{\omega} \\
\infty \\
\infty\end{array}$} & \multicolumn{4}{|c|}{ Unit cell } & \multirow[t]{2}{*}{ Remarks, references } & \multicolumn{2}{|c|}{$\begin{array}{c}\text { Tungsten } \\
\text { bronze-type } \\
\text { sub-cell } \\
Z=5 \\
\end{array}$} \\
\hline & & $a_{o}$ & $b_{o}$ & $c_{0}$ & $Z$ & & $a_{0}^{\prime}$ & $c_{0}^{\prime}$ \\
\hline $\begin{array}{c}(\mathrm{Na}, \mathrm{K}, \mathrm{Pb}, \mathrm{Li})_{0.586}(\mathrm{Ta}, \mathrm{Nb}, \mathrm{Al})_{2.216} \\
(\mathrm{O}, \mathrm{OH})_{6} \text { (rankamaite) } \ldots \ldots \ldots \ldots\end{array}$ & o & 17.19 & 17.70 & 3.939 & 10 & This paper & 12.34 & 3.933 \\
\hline $\left.\mathrm{Ba}_{0.545} \mathrm{Ta}_{2,18} \mathrm{O}_{6}{ }^{*}\right) \quad\left(\mathrm{BaTa}_{4} \mathrm{O}_{11}\right)$ & o & 17.55 & 17.65 & 3.905 & 10 & G., 1967 & 12.45 & 3.905 \\
\hline $\left.\mathrm{PbTa}_{2} \mathrm{O}_{6} *\right) \ldots \ldots \ldots \ldots \ldots \ldots \ldots \ldots \ldots \ldots \ldots$ & o & 17.68 & 17.72 & $2 \times 3.877$ & 20 & G., 1964 & 12.49 & 3.877 \\
\hline $\mathrm{PbNb}_{2} \mathrm{O}_{6} \ldots \ldots \ldots \ldots \ldots \ldots \ldots$ & o & 17.63 & 17.93 & 3.868 & 10 & R., (cf. F. and L., 1958) & 12.56 & 3.862 \\
\hline $\mathrm{K}_{0.8} \mathrm{Bi}_{0.4} \mathrm{Nb}_{2} \mathrm{O}_{6} \quad\left(\mathrm{~K}_{2} \mathrm{BiNb}_{5} \mathrm{O}_{15}\right.$ & o & 17.75 & 17.90 & $2 \times 3.92$ & 20 & Is. & 12.60 & 3.92 \\
\hline $\mathrm{Na}_{0.572} \mathrm{Ta}_{2.286} \mathrm{O}_{6} \quad\left(\mathrm{Na}_{2} \mathrm{Ta}_{8} \mathrm{O}_{21}\right)$ & $\mathrm{t}$ & $\sim 12.5$ & - & 3.95 & 5 & $\begin{array}{l}\text { Tripled } a \text { or } b \text { axis may also } \\
\text { be expected. W. and S., } \\
1965\end{array}$ & $\sim 12.5$ & 3.92 \\
\hline $\left.\mathrm{Na}_{0.572} \mathrm{Nb}_{2.286} \mathrm{O}_{6} *\right)\left(\mathrm{Na}_{2} \mathrm{Nb}_{8} \mathrm{O}_{21}\right)$ & o & 12.45 & 36.97 & 3.910 & 15 & $\begin{array}{l}\text { The basic bronze unit trip- } \\
\text { led in the }[010] \text { direction. } \\
\text { W. and S., } 1965\end{array}$ & 12.4 & 3.910 \\
\hline $\left.\mathrm{Na}_{0.75} \mathrm{Nb}_{2.26} \mathrm{O}_{6}{ }^{*}\right)$ & o & 12.45 & 36.93 & 3.95 & 15 & & $\sim 12.4$ & 3.95 \\
\hline $\left.\mathrm{K}_{1.06} \mathrm{Ta}_{2.13} \mathrm{O}_{6} *\right)$ & $\mathrm{t}$ & 12.57 & - & 3.969 & 5 & S. and $\mathrm{K}$. & 12.57 & 3.969 \\
\hline $\left.\mathrm{K}_{1.06}^{1.06} \mathrm{Ta}_{2.13} \mathrm{O}_{6} *\right)$ & $\mathrm{t}$ & 37.29 & 一 & 3.878 & 45 & $\begin{array}{l}\text { Tripled bronze phase. W. } \\
\text { and S., } 1965\end{array}$ & 12.43 & 3.878 \\
\hline $\mathrm{K}_{0.75} \mathrm{Nb}_{2.26} \mathrm{O}_{6} \quad\left(\mathrm{KNb}_{3} \mathrm{O}_{8}\right) \ldots$ & $\mathrm{t}$ & 37.71 & - & 3.939 & 45 & W. and S., 1965 & 12.57 & 3.939 \\
\hline $\mathrm{SrTa}_{2} \mathrm{O}_{6} \ldots \ldots \ldots \ldots \ldots \ldots \ldots \ldots \ldots$ & $\mathrm{t}$ & 12.304 & - & 3.926 & 5 & W. and S., 1967 & 12.304 & 3.926 \\
\hline $\left.\mathrm{Sr}_{0.545} \mathrm{Ta}_{2.18} \mathrm{O}_{6} *\right) \quad\left(\mathrm{SrTa}_{4} \mathrm{O}_{11}\right) \ldots$ & $\mathrm{t}$ & $3 \times 17.53$ & - & $2 \times 3.865$ & 180 & G., 1963 & 12.43 & 3.865 \\
\hline
\end{tabular}

*) comparison of measured density with the calculated refers to intact oxygen lattices, i.e., 30 oxygen atoms in a tungsten bronze-type sub-cell.

$\mathrm{G}=$ Gasperin, $\mathrm{R}=$ Roth, 1957; F and $\mathrm{L}=$ Francombe and Lewis, 1958; Is = Ismailzade, 1963; W and $\mathrm{S}=$ Whiston and Smith; $\mathrm{A}=$ Andersson, 1963; S and $\mathrm{K}=$ Sawaguchi and Kikuchi, 1964.

\section{Crystal-chemical discussion}

Table 3 lists a number of structurally related compounds, all based on the tungsten bronzetype structure. Some are tetragonal, some orthorhombic, but all have the same sub-cell. Rankamaite is orthorhombic, like the synthetic compounds $\mathrm{Na}_{2} \mathrm{Nb}_{8} \mathrm{O}_{21}, \mathrm{BaTa}_{4} \mathrm{O}_{11}, \mathrm{PbTa}_{2} \mathrm{O}_{6}$, $\mathrm{PbNb}_{2} \mathrm{O}_{6}$ and $\mathrm{K}_{2} \mathrm{BiNb}_{5} \mathrm{O}_{15}$. The last four either have cell dimensions similar to those of rankamaite or their $c$-axis is doubled. In ideal tungsten bronze structure, the ratio of small atoms ( $\mathrm{Ta}, \mathrm{Nb}$ ) to anions (O) ought to be $1: 3$. As seen in Table 3, in most cases the ratio is greater than $1: 3$. Therefore, either anion vacancies or interstitial tantalum or niobium atoms must be present, or the extra tantalum and niobium atoms occupy the large cation positions. In $\mathrm{Ta}$ ble 3 , it has been postulated that the asterisked componds (for which correlations of calculated and measured density are available) have intact oxygen lattices with extra tantalum or niobium atoms either in interstitial positions or in those large cation positions which are not occupied by $\mathrm{Na}, \mathrm{K}, \mathrm{Ba}, \mathrm{Sr}$, etc. The left side of the first column - unit cell content $/ Z$ - gives the content of one fifth of the tungsten bronzetype sub-cell $(Z=5)$ : i.e., the chemical formulae in brackets (right side of the same column) have been recalculated on the basis of 6 oxygen atoms. Using this same principle of intact oxygen lattices the atomic ratio in rankamaite was calculated to $6(\mathrm{O}+\mathrm{OH})$.

The rankamaite unit cell content - 10 $(\mathrm{Na} \ldots)_{0.586}(\mathrm{Ta} \ldots)_{2.216}(\mathrm{O} \ldots)_{6}$ - shows that 2.16 small cations per cell must be distributed either in interstitial positions, or in the positions of large cations. The formula given is close to 
$\mathrm{Na}_{0.572} \mathrm{Ta}_{2.286} \mathrm{O}_{6}$ or $\mathrm{Na}_{2} \mathrm{Ta}_{8} \mathrm{O}_{21}$, synthesized by Whiston and Smith (1965). In this case, according to Whiston and Smith, only rather small and badly twinned crystals were produced. These were claimed to confirm the tetragonal tungsten bronze cell with approximate cell dimensions $a_{o}=12.5$ and $c_{0}=3.92 \AA$. The corresponding $\mathrm{Nb}$-compound, $\mathrm{Na}_{0.572} \mathrm{Nb}_{2.286} \mathrm{O}_{6}$ has the same structure, but the basic bronze unit is tripled in the [010] direction.

The tetragonal or tripled bronze structures are also represented by $\mathrm{K}_{1.06} \mathrm{Ta}_{2.13} \mathrm{O}_{6}$, $\mathrm{K}_{0.75} \mathrm{Nb}_{2.26} \mathrm{O}_{6}, \mathrm{Na}_{0.75} \mathrm{Nb}_{2.26} \mathrm{O}_{6}$ like many other componds (Table 3). Thus, it is reasonable to assume that a compound corresponding to the composition of rankamaite should be structurally related to the tungsten bronzes. Also it becomes easy to substitute $\mathrm{Na}$ and/or $\mathrm{K}$ by $\mathrm{Pb}$; the corresponding lead tantalate might be iso- structural with rankamaite. Table 3 reveals, however, that rankamaite has no exact counterpart among the synthetic compounds so far produced. It includes such synthetic $\mathrm{Na}$ and $\mathrm{K}$ tantalates and niobates as are based on the tungsten bronze structure. Most likely, rankamaite is an orthorhombic polymorph of the $1: 4$ compound $\mathrm{Na}_{2} \mathrm{Ta}_{8} \mathrm{O}_{21}$, where the deformation of the tetragonal bronze structure is due to the partial replacement of sodium by potassium, lead and lithium and the partial replacement of tantalum by niobium and aluminium (?).

So far a complete single-crystal study of rankamaite is lacking. The possibility of superstructure in it should be kept in mind. Moreover, the badly twinned crystals of synthetic $\mathrm{Na}_{2} \mathrm{Ta}_{8} \mathrm{O}_{21}$ might be only pseudotetragonal, as rankamaite.

\section{REFERENCES}

Agassiz, J. F. (1954) Géologie et pegmatites stannifères de la région Mumba-Numbi Kivu (Congo Belge). Comité National du Kivu. Nouvelle série 7, Bruxelles, $1-78$.

Andersson, Sten (1963) Structural studies on two sodium niobates. Abstracts of the Communications. Sixth International Congress and Symposia. International Union of Crystallography. A 22.

Bowley, H. (1939) Simpsonite from Tabba Tabba, Western Australia. Journ. Roy. Soc. Western Australia, $25,89-92$.

Francombe, M. H. and Lewis, B (1958) Structural, dielectric properties of ferroelectric lead metaniobate. Acta Cryst. 11, 696-703.

Gasperin, M. (1963) Étude cristallographique d'un oxyde double de tantale et de strontium. Bull. Soc. franç. Min. Crist. 86, 386-388.

- (1964) Sur la position des atomes lourds dans le métatantalate de plomb ferroeléctrique $\mathrm{PbTa}_{2} \mathrm{O}_{6}$. Bull. Soc. franç. Min. Crist. 87, 50-52.

- (1967) Structure cristalline du bronze de tungstène: $\mathrm{BaO} .2 \mathrm{Ta}_{2} \mathrm{O}_{5}$. Bull. Soc. franç. Min. Crist. 90, 172175.
Guerchais, Jacques Émile (1962) Réactions entre l'oxyde de niobium et le carbonate de potassium par voie seche; hydrolyse des produits obtenus (III). Bull. Soc. chim. France. 103-107.

Ismailzade, I. G. (1963) An X-ray study of some compounds of composition $\mathrm{A}\left(\mathrm{B}_{\mathrm{x}}^{\prime}, \mathrm{B}^{\prime \prime}{ }_{2-\mathrm{x}}\right) \mathrm{O}_{6},\left(\mathrm{~A}_{0.8}^{\prime}, \mathrm{A}^{\prime \prime}{ }_{0.4}\right)$ $\mathrm{Nb}_{2} \mathrm{O}_{6}$ and $\left(\mathrm{Ba}_{0.4}, \mathrm{Sr}_{0 \cdot 2}, \mathrm{Ca}_{0 \cdot 4}\right) \mathrm{TiO}_{3}(\mathrm{~A}=\mathrm{Sr}, \mathrm{Ba}$; $\left.\mathrm{B}^{\prime}=\mathrm{Fe}, \mathrm{Mg} ; \mathrm{B}^{\prime \prime}=\mathrm{Nb} ; \mathrm{A}^{\prime}=\mathrm{K} ; \mathrm{A}^{\prime \prime}=\mathrm{La}, \mathrm{Bi}\right)$. Soviet Physics-crystallography, vol. 8, no. 3, 274-277.

v. KNORring, O. (1962) Mineralogical investigations: new minerals. 6, Ann. Rept. Res. Inst. African Geology. Univ. Leeds, 47-48.

- (1965) Mineralogical studies: niobium-tantalum minerals. 9, Ann. Rept. Res. Inst. African Geology. Univ. Leeds, 42-43.

Macgregor, A. M. (1946) Simpsonite and other tantalites from Bikita, S. Rhodesia. Min. Mag. 27, 157 -165 .

Rотн, H. (1957) Unit-cell data of the lead niobate $\mathrm{PbNb}_{2} \mathrm{O}_{6}$. Acta Cryst. 10, 437.

Safiannikoff, A. and van Wambeke, L. (1961) Sur un terme plombifère $\mathrm{du}$ groupe pyrochlore-microlite. Bull. Soc. franç. Min. Crist. 84, 382-384. 
Sawaguchi, Etsuro and Kikuchi, Atsushi (1964)

Crystal structure and the dielectric properties of $\mathrm{K}_{2} \mathrm{O} .2 \mathrm{Ta}_{2} \mathrm{O}_{5}$. J. Phys. Soc. Japan, 19, 579.

Whiston, C. D. and Smith, A. J. (1965) Double oxides containing niobium or tantalum. I. Systems including alkali metals. Acta Cryst. 19, 169-173.
Whiston, C. D. and Smith, A. J. (1967) Double oxides containg niobium and tantalum. II. Systems involving strontium and barium. Acta Cryst. 23, 82-84.

Manuscript received, August 6, 1968. 